石油技術坫合誌第 23 爸 第 4 凯 (昭和 33 年 7 月)

JOURNAL OF THE JAPANESE ASSOCIATION OF PETROLEUM TECHNOLOGISTS

VOL. 23, NO. 4 (July, 1958)

\title{
古丹別層の堆積盈の沈降運動
}

松 野 久 也*

(昭和 33 年 3 月 10 日受理)

\section{The Depression of the Sedimentary Basin of the Kotambetsu Formation}

By

\section{Kyūya MATSUNO}

\begin{abstract}
In this paper the writer has dealt with the depression of the basin in which the Kotambetsu formation was deposited.

The Kotambetsu formation, which has very broad distribution with the equivalent Kawabata and Masuporo formations in the western side of the meridional mountain range of Hokkaido, shows very characteristic condition of sedimentation such as tramendous thickness, remarkable development of cyclothem, existence of slump sheets or balls in the formation, and etc.

These remarkable features on sedimentation caused from the depression reached to $6,300 \mathrm{~m}$. deep, which had been continued during the deposition of the Kotambetsu formation. The movement long continued in Miocene age must be noticed in the area where the formation equivalent to the Kotambetsu formation developed.
\end{abstract}

\section{緒言}

昭和 29,30 年の両年にわたる 5 万分の 1 地質㘡幅「達 布」”の調查の結果, 小平策川北岸地域で築別層堆積後, 古丹別層堆積前に, 築別層の上位に占第三系上部の達布 層を㣫上せしめた著しい構造運動があつたことが明らか となつた。以来この時期の連動について注目して来たの であるが，他の地域で古丹別層に対比される地層と，そ の下位に横たわる地層との間に，このような急激な運動 の認められるところは全くといつてょい位認められず, かえつて古丹別層および同層準の堆積中における運動 が，きわめて特巽であることが判明した。

最近になつて, 上述の達布図幅の北に接する三溪・築 別炭砸の両図幅内に分布する古丹別癏がほが明らかにせ られ，一応の結論を得たのでこつにその概要を予報す る。

本論に大るに先立つて, この問題の解決に重要な端緒 となつた御意見を奇せられた東北大学の浅野清教授を初
め，この地域の地質調査に協力を得た地質調査所北海道 支所の山口昇一技官, この小論をまとめるに当つて終始 激励と多くの有益な御教示をいたざいた地質調査所北海. 道支所地質課の諸兄に対して厚くお礼申し上げる。

\section{古丹別層とその分布}

古丹別層は天北地方の増幌層, 夕張地方の川端層, 日 高地方の振老層などとともに，北海道の中軸をなす日高 山脈の西縁沿いに生じた著しい沈降帯に, 著しく多量の 岩砕が供給せられた結果形成された地層であつて, 砅 岩・砂岩・泥岩の周期的互層からなり, しばしば乱堆積 を示し，地層の厚い割合に化石が非常に少ないとい5特 徵をもつている。

古丹別層といら名称は, 初山別村第一栄から小平䔀川 北岸までの間，日本海に臨む地域に分布する上述のよ5 な地層に対して与えられ, 初山別以北では増幌層と呼ば れている(第1図参照)。

* 地犋調查所北㴼道支所 
第 1 図地質 図

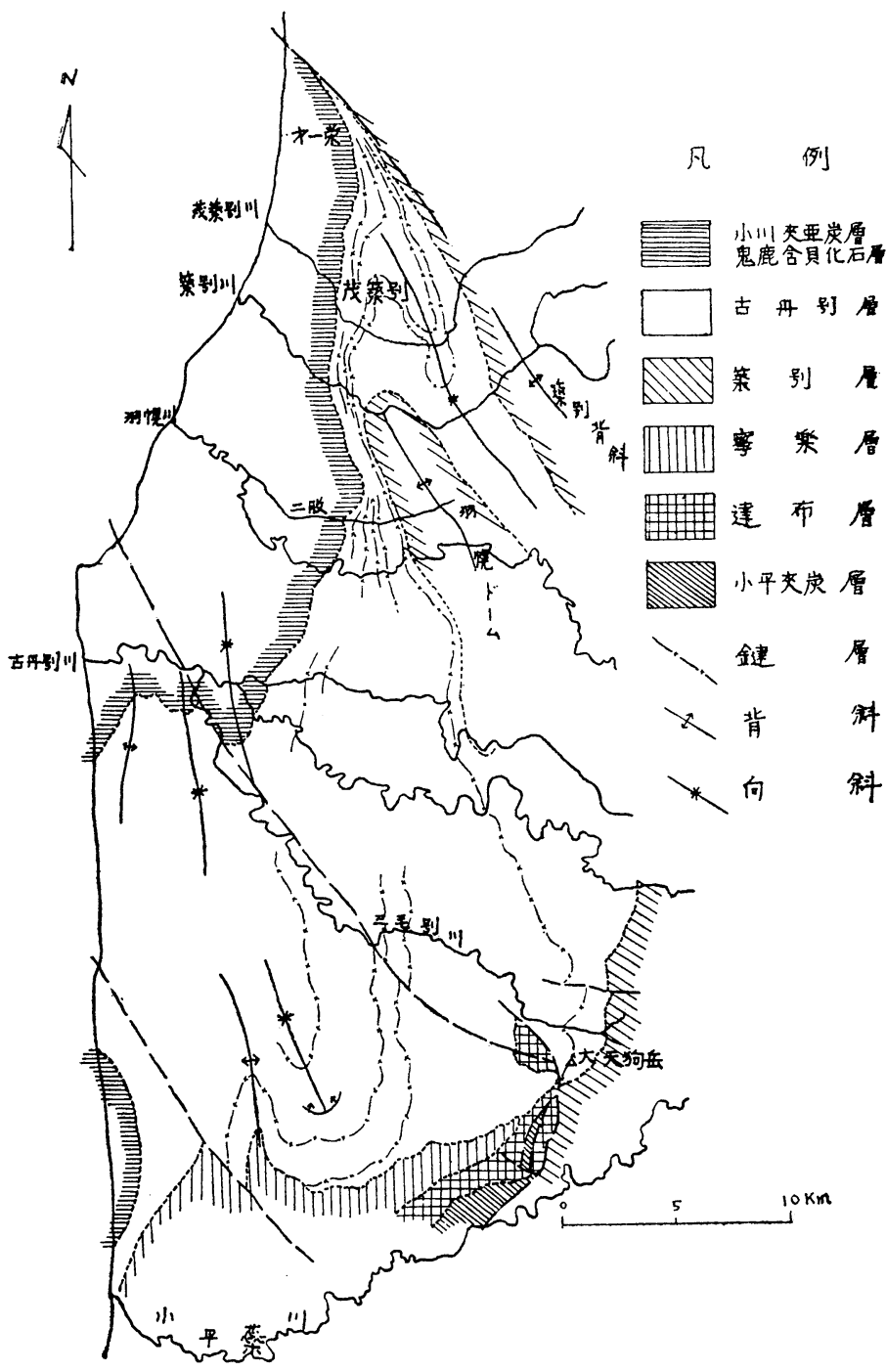

域の北端の第一栄附近で約 $600 \mathrm{~mm}$ で あるが，順次南へ追跡すると，茂築別 附近で約 $2,400 \mathrm{~m}$, 築別川下流で約 $900 \mathrm{~m}$, 二股附近で $2,350 \mathrm{~m}$ ，これより 南へ徐々に厚くなり, 三毛別川流域で 最大 $6,300 \mathrm{~m}$ に達する。こ〉から南 では急激に薄くなり, 小平藥川川口附 近で 400〜 $500 \mathrm{~m}$ となる。

またここの地層中に $4 \sim 5$ 枚の厚さ 数 $\mathrm{m}$ から $900 \mathrm{~m}$ に達する 流紋岩質凝 灰岩層があつて, 非常に有効な鍵曆と して，いずれもかなり広範囲に追跡さ れる。これらの鍵層の追跡は末だ充分 ではないが，現在までの資料から，古 丹別層の南北方向における層厚の变化 と鍵層との関係を示すと第 2 図の通り である。

\section{堆積盆の沈降量}

第 2 涩から, 古丹別層の堆積盈には 羽幌ドーム附近の沈降の著しくない部 分を距て〉，2つの社降の中心があつ て，それぞれ異なつた汇降量を示して いる。今仮りに, 北部の沈降帯を築別 洗降帯, 南部のそれを三毛別洁降帯と し, その間の両側の沈降に対して盛上 つている羽幌ドーム附近を羽幌上昇帯 とすると, 羽幌上昇带と築別沈降帯と は $1,500 \mathrm{~m}$, 三毛別洗降帯とは実に $5,400 \mathrm{~m}$ の運動量の差が浔められる。

\section{堆積物と沈路量との開係}

上述のある所では数 $1,000 \mathrm{~m}$ に及んだ 大きな沈降運動は，古丹別層堆積中弓続

\section{古丹別層と上下の地層との境界}

占丹別層の上限は，整合関係をもつて小川夾亚炭尿お よびその浅海相である鬼鹿含貝化石層に接する ${ }^{2131 。 そ の ~}$ 下位の地層との関係は, 大天狗岳を㣣んで北部と南西部 で著しい差異がある。すなわち大天狗岳以北では, 全般 に平行不整合をもつて下位の築別層に接し, 大天狗岳の 南西では, 築別層の上に衝上した達布層に直接し, これ より西に向かつて順次下部を欠きつ〉, 達布層の上に重 る寧楽層 (築別層) を追覆 (overlap)する”。

\section{層厚と鍵層との関係}

古丹別層は地域毎に層厚の著しい变化があり, この地
いて行われたもので, 堆積物の面にもこうよ5に異常に 瑯夆した所と，そうでないところとの差がきわめてよく あらわれている。

古丹別層の堆積状沉をみると, 碟岩から粗粒砂岩・細 粒砂岩, 続いて砂岩・泥岩の互層, 泥岩とい5輪迴 (cycle) をくりかえしている。このような輪廻は汇降量の著しい そころでは異常に大きく，そうでないところでは数 $\mathrm{m}$ というのが普通である。すなわち, もつとも沈降量の著 しい三毛別川中流で観察されたところでは，1輪㢠の厚 さが 250〜300 m に達するものがあり，このようなとこ ろではしばしば乱堆積 (slumping sheet あるいはこれが ちぎれて径 10 数 $\mathrm{m}$ の同時磁となつて，おびたざしく碟 岩中にとりこまれている) を示している。 


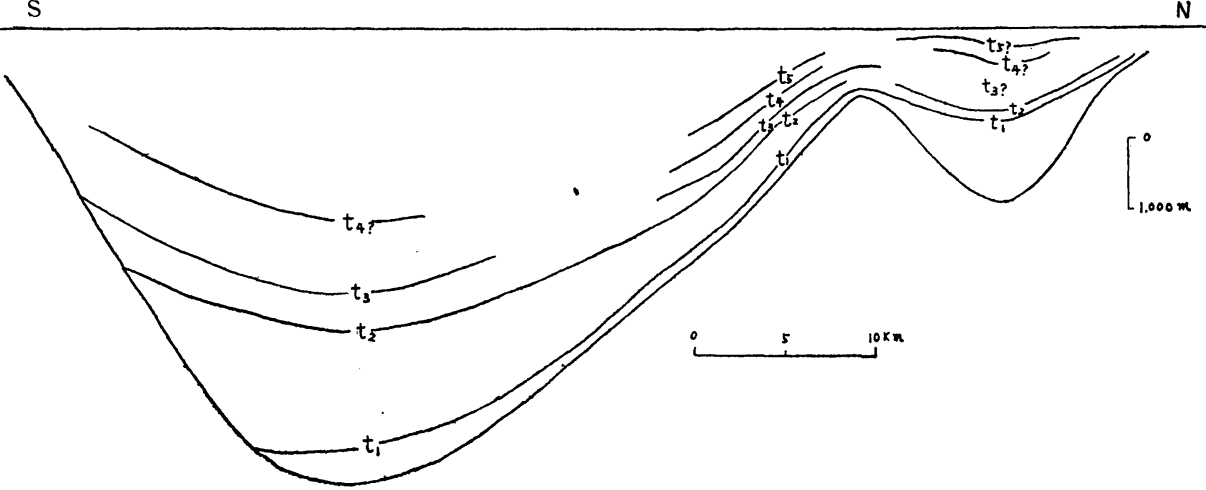

堆積物については別の機会に詳述するので，こ〉では これにとよ゙めておく。

\section{考察}

以上から古丹別層の堆積盆は, 上昇帯によつて距てら れたいくつかの沈降の中心があつて，その中心毎におの おの異なつた沈降を行つたもので，この沈降運動は古丹 別層堆積中弓続いて行われたものである。またその堆積 物の状況から, 最初に堆積盈となつた四所ができて,こ フに堆積物が集積されたとい5よりは，断続的な沈降と 堆積物の集積とが前後しつ〉, 終極には最大 $6,300 \mathrm{~m}$ に も達するような沈降が, 進行して行つたものと考えられ るのである。しかし，この堆積㿿へ集積された岩砕が， いかなるところ(深さ)で沈積したかは，現在の段階では 不明である。

最近，古丹別層と 同時代の 川端層や日高地方の受㝋 層・振老層にも，このような事実が判明しているが，こ れらの地方では，これらの地層と下位の滝ノ上層および 相当層との間は全く整合的で, 古丹別層の堆積䀂の北部 に見られるよ5な平行不整合 (diastem)さえ認められな いのである。

したがつて中新世中葉から後期にかけての地殼運動 は, 古丹別層・川端層・振老層の堆積中の運動が支配的 であつたと考えられるのである。ところがこう見てくる と, 小平䔉川北岸地域にのみ見られる中新世中葉に拈 る古丹別層堆積前の構造運動と異常な追覆の現象とは, いかなる背景のもとに生じたのであるか, きわめて與味 ある問題である。

これに関して注目されることは

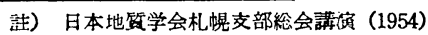

（1）この地域を境にして，南には古第三系が発详する がこれより北部にはこの時代の地簤を全く欠くこと

（2）この附近が，寧楽層と築別層のおのおのの堆積盈. の境界であること,すなわち魚住悟註)によれば，川端期 中葉の動物群は北から侵大した築別動物群と, 南から侵 大した門の沢動物群とに分けられ，その両者を隔てた barrier は北緯 $44^{\circ}$ 附近（すなわちこの附近がそれに当 る)にあるとしている。

すなわち，この地域は古くからこのよ5に相対立する 地域の境界に当つていたことが，容易に想像されるとこ ろである。この点の吟味は，さらに第三系の基盤である 白㢥系あるいはそれ以前の地層についての考察を必要と するのであろ5が，次の点だけは明らかである。

この地域は他の地域と異なつて, 三毛別の 6,300 $\mathrm{m}$ に およんだ著しい沈降帯と, その南の非沈降帯とが,きわ めて接近しているところであつて，激しい沈降帯の縁辺 部において，このような追覆現象となつて現われ，古丹 別層とそれより下位の地層との間に，構造運動を示すよ うな傾斜不整合が生じたのであろうと考えられる。

このような現われ方をした原因については，さらにこ の周辺の研究に侯たねばならない。

\section{文 献}

1）対馬坤六・田中啓策・松野久也・山口昇一：5 万 分の 1 地質図幅「達布」（旭川一第 38 号）および 説明書, 地質調查所, 1958.

2）対馬坤六・松野久也：山口昇一：5 万分の 1 地質 図幅「苫前」(旭川一第 33 号), および説明書, 地 質調查所, 1954.

3）対馬坤六・松野久也・山口杽一：5 万分の 1 地資 図幅「鬼鹿」(旭川一第 37 号), および説明書, 地 質調查所, 1956. 